\title{
Silver(I) based dinuclear metallacycles with free thiophenyl/thiomethyl units
}

\author{
SARITA YADAV ${ }^{\mathrm{a}}$, DEEPAK GUPTA ${ }^{\mathrm{a}}$ and MALAICHAMY SATHIYENDIRAN ${ }^{\mathrm{a}, \mathrm{b}, *}$ \\ ${ }^{a}$ Department of Chemistry, University of Delhi, Delhi 110 007, India \\ ${ }^{\mathrm{b}}$ School of Chemistry, University of Hyderabad, Hyderabad, 500046 India \\ e-mail: msathi@uohyd.ac.in
}

MS received 1 October 2015; revised 8 December 2015; accepted 10 December 2015

\begin{abstract}
Three dinuclear, ionic and homoleptic metallacycles decorated with free thiophenyl or thiomethyl units were synthesized using $\operatorname{AgOS}\left(\mathrm{O}_{2}\right) \mathrm{CF}_{3}$ and benzimidazole derived ditopic $\mathrm{N}$-donor ligands at ambient condition. The complexes were characterized by analytical and spectroscopic (IR and ${ }^{1} \mathrm{H}$ NMR) techniques and two of the complexes were structurally characterised through single crystal X-ray diffraction.
\end{abstract}

Keywords. Metallacycle; benzimidazole; silver; supramolecule; thiophenyl; thiomethyl

\section{Introduction}

The coordination chemistry of silver(I) ion has been studied widely from the perspective of synthesis of molecular and supramolecular frameworks for materials and biological applications. ${ }^{1}$ The property of diverse coordination numbers and geometries exhibited by silver ion when combined with a judicious choice of coordinating ligands facilitate the formation of several interesting one-, two- and three dimensional supramolecular architectures. ${ }^{2}$ Among these supramolecules, discrete silver(I)-based supramolecular coordination complexes i.e., metallacycles are a notable class. ${ }^{3-14}$ Nitrogen donor ligands explored till now for the synthesis of silver-based metallacycles are mostly pyridylbased motif ${ }^{3}$ and a countable pyrazole, ${ }^{4,5}$ pyrimidine, ${ }^{6}$ imidazole, ${ }^{7}$ benzimidazole, ${ }^{8}$ pyridylpyrimidine, ${ }^{9}$ benzotriazole, ${ }^{10}$ Schiff base, ${ }^{11}$ thioquinoline, ${ }^{12}$ adenine, ${ }^{13}$ and dipyrin ${ }^{14}$ derivatives. However, the design and synthesis of silver(I)-based metallacycles decorated with covalently bonded uncoordinated heterocycles/softdonors is a challenge due to the high affinity of heterocyclic unit to silver(I) ion that is regarded as a soft acid which favours coordination to a soft base. ${ }^{5,12} \mathrm{We}$ have recently reported considerable variety of rhenium based metallacycles utilizing furan/thiophene/thiomethyl functional units attached benzimidazolyl based ligands (figure 1) with interesting structural and photophysical properties. ${ }^{15}$ Herein, we report a new class of silver(I)based metallacycles decorated with free thiophenyl and

*For correspondence thiomethyl units. Self-assembly of three dinuclear, ionic and homoleptic complexes was achieved using silver trifluoromethanesulfonate $\left(\mathrm{AgOS}(\mathrm{O})_{2} \mathrm{CF}_{3}\right)$ and a ditopic $\mathrm{N}$-donor ligand. The complexes were characterized by elemental analysis, FT-IR, mass spectrometry and nuclear magnetic resonance spectroscopic techniques. The molecular structures of two of the complexes were further confirmed by single-crystal X-ray diffraction analysis.

\section{Experimental}

\subsection{Materials and general procedures}

Ligands $\left(\mathrm{L}^{1}, \mathrm{~L}^{2}\right.$ and $\mathrm{L}^{3}$ ) were synthesized according to reported procedure and were stable in moisture and air. ${ }^{15 \mathrm{~g}, 15 \mathrm{j}} \mathrm{AgOS}(\mathrm{O})_{2} \mathrm{CF}_{3}$ was procured from Sigma Aldrich. Analytical grade $\mathrm{CH}_{2} \mathrm{Cl}_{2}$, and $\mathrm{CH}_{3} \mathrm{OH}$ were purchased and used as received. Elemental analysis was performed on an Elementar Analysen systeme GmbH Vario EL-III instrument. FT-IR spectral data were obtained on a Shimadzu IR435 spectrometer using $\mathrm{KBr}$ pellet in the frequency range $400-4000 \mathrm{~cm}^{-1} \cdot{ }^{1} \mathrm{H}$ NMR spectra were recorded on a JEOL ECX 400 NMR spectrometer. The chemical shifts are reported in parts per million (ppm) relative to residual solvent signal.

\subsection{Synthesis of the complexes 1-3: General procedure for synthesis of metallacycles}

$\mathrm{AgOS}(\mathrm{O})_{2} \mathrm{CF}_{3}$ in $\mathrm{CH}_{3} \mathrm{OH}$ was added dropwise to a ditopic ligand in $\mathrm{CH}_{2} \mathrm{Cl}_{2}$ in a round bottom flask 


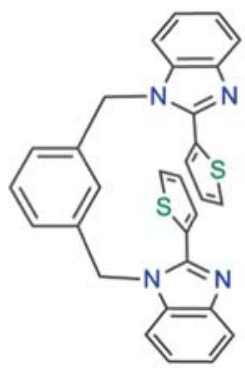

$L^{1}$

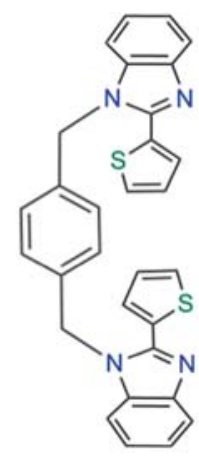

$\mathrm{L}^{2}$

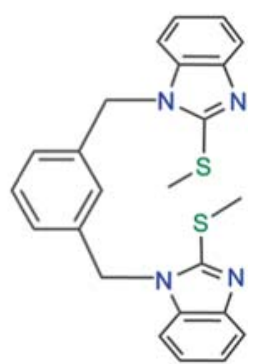

$\mathrm{L}^{3}$
Figure 1. Ditopic ligands used for the synthesis of metallacycles.

with constant stirring at room temperature. Very fine precipitate was obtained immediately in the reaction mixture. It was stirred overnight. The resulting product as precipitate was filtered, and allowed to dry in the air. The filtrate was kept undisturbed. Crystals of metallacycle were obtained from the filtrate.

2.2a Synthesis of metallacycle 1: Metallacycle $\mathbf{1}$ was obtained from $\operatorname{AgOS}(\mathrm{O})_{2} \mathrm{CF}_{3}(25.5 \mathrm{mg}, 0.099 \mathrm{mmol})$, $\mathrm{CH}_{3} \mathrm{OH}(5 \mathrm{~mL}), 1,3$-bis((2-(thiophen-2-yl)-benzimidazol-1-yl)methyl)benzene (50 $\mathrm{mg}, 0.099 \mathrm{mmol})$, and $\mathrm{CH}_{2} \mathrm{Cl}_{2}$ (5 mL). Yield: $93 \%$ (70 mg, $0.046 \mathrm{mmol}$ ). Anal. Calcd. (\%) for $\mathrm{C}_{62} \mathrm{H}_{44} \mathrm{~N}_{8} \mathrm{O}_{6} \mathrm{~F}_{6} \mathrm{~S}_{6} \mathrm{Ag}_{2} \cdot \mathrm{H}_{2} \mathrm{O}\left(M_{\mathrm{r}} 1519.18\right.$ + 18.02): C, 48.44; H, 3.02; N, 7.29, S 12.52. Found: C, 48.18; H, 2.72; N, 7.41, S 12.56. FT-IR $\left(\mathrm{KBr}, \mathrm{cm}^{-1}\right)$ : $v(\mathrm{C}=\mathrm{N}) 1565(\mathrm{w}, \mathrm{br}) .{ }^{1} \mathrm{H}$ NMR $\left(400 \mathrm{MHz}, \mathrm{DMSO}-d_{6}\right)$ : $\delta 5.68\left(\mathrm{~s}, 4 \mathrm{H}, \mathrm{H}^{8}\right), 6.73\left(\mathrm{~s}, 1 \mathrm{H}, \mathrm{H}^{11}\right), 6.95(\mathrm{~d}, J=7.3 \mathrm{~Hz}$, $\left.2 \mathrm{H}, \mathrm{H}^{9}\right), 7.06-7.08\left(\mathrm{~m}, 2 \mathrm{H}, \mathrm{H}^{4^{\prime}}\right), 7.21-7.30(\mathrm{~m}, 5 \mathrm{H}$, $\left.\mathrm{H}^{5,6,10}\right), 7.36\left(\mathrm{~d}, J=3.7 \mathrm{~Hz}, 2 \mathrm{H}, \mathrm{H}^{3^{\prime}}\right), 7.47(\mathrm{~d}, J=$ $\left.8.2 \mathrm{~Hz}, 2 \mathrm{H}, \mathrm{H}^{7}\right), 7.71\left(\mathrm{~d}, J=7.8 \mathrm{~Hz}, 2 \mathrm{H}, \mathrm{H}^{4}\right), 7.74$ $\left(\mathrm{dd}, J=5.0,0.9 \mathrm{~Hz}, 2 \mathrm{H}, \mathrm{H}^{5^{\prime}}\right)$. Crystals suitable for X-ray diffraction were obtained from $\mathrm{CH}_{2} \mathrm{Cl}_{2}: \mathrm{CH}_{3} \mathrm{OH}$ mixture.

2.2b Synthesis of metallacycle 2: Powder of 2 was obtained from 1,4-bis((2-(thiophen-2-yl)-benzimidazol-1yl)methyl)benzene (50 mg, $0.099 \mathrm{mmol}), \mathrm{CH}_{2} \mathrm{Cl}_{2}(5 \mathrm{~mL})$, $\mathrm{AgOS}(\mathrm{O})_{2} \mathrm{CF}_{3}(25.5 \mathrm{mg}, 0.099 \mathrm{mmol})$, and $\mathrm{CH}_{3} \mathrm{OH}$ (5 mL). Yield: $70 \%$ (53 mg, $0.0349 \mathrm{mmol}$ ). Anal. Calcd (\%) for $\mathrm{C}_{62} \mathrm{H}_{44} \mathrm{~N}_{8} \mathrm{O}_{6} \mathrm{~F}_{6} \mathrm{~S}_{6} \mathrm{Ag}_{2} \cdot \mathrm{CH}_{2} \mathrm{Cl}_{2}\left(M_{\mathrm{r}} 1519.18+\right.$ 84.93): C, 47.17; H, 2.89; N, 6.99, S 11.99. Found: C, 47.55; H, 3.08; N, 7.25, S 11.44. FT-IR $\left(\mathrm{KBr}, \mathrm{cm}^{-1}\right)$ : $v(\mathrm{C}=\mathrm{N}) 1562(\mathrm{w}, \mathrm{br}) .{ }^{1} \mathrm{H}$ NMR $(400 \mathrm{MHz}, \mathrm{DMSO}-$ $\left.d_{6}\right): \delta 5.71\left(\mathrm{~s}, 4 \mathrm{H}, \mathrm{H}^{8}\right), 7.01\left(\mathrm{~s}, 4 \mathrm{H}, \mathrm{H}^{9}\right), 7.15(\mathrm{t}, J=$ $\left.4.6 \mathrm{~Hz}, 2 \mathrm{H}, \mathrm{H}^{4^{\prime}}\right), 7.21-7.28\left(\mathrm{~m}, 4 \mathrm{H}, \mathrm{H}^{5,6}\right), 7.47(\mathrm{~d}$, $\left.J=3.6 \mathrm{~Hz}, 2 \mathrm{H}, \mathrm{H}^{3^{\prime}}\right), 7.52(\mathrm{dd}, J=6.7,2.6 \mathrm{~Hz}, 2 \mathrm{H}$, $\left.\mathrm{H}^{7}\right), 7.69-7.72\left(\mathrm{~m}, 2 \mathrm{H}, \mathrm{H}^{4}\right), 7.77(\mathrm{~d}, J=5.0 \mathrm{~Hz}$, $\left.2 \mathrm{H}, \mathrm{H}^{5^{\prime}}\right)$. 2.2c Synthesis of metallacycle 3: Metallacycle 3 was obtained from 1,3-bis((2-(methylthio)-benzimidazol-1yl)methyl)benzene ( $86 \mathrm{mg}, 0.200 \mathrm{mmol}), \mathrm{CH}_{2} \mathrm{Cl}_{2}(5 \mathrm{~mL})$, $\mathrm{AgOS}(\mathrm{O})_{2} \mathrm{CF}_{3}(51.5 \mathrm{mg}, 0.200 \mathrm{mmol})$, and $\mathrm{CH}_{3} \mathrm{OH}$ (5 mL). Yield: $83 \%$ (113.5 mg, $0.083 \mathrm{mmol})$. Anal. Calcd. (\%) for $\mathrm{C}_{50} \mathrm{H}_{44} \mathrm{~N}_{8} \mathrm{O}_{6} \mathrm{~F}_{6} \mathrm{~S}_{6} \mathrm{Ag}_{2} \cdot 2 \mathrm{H}_{2} \mathrm{O}\left(M_{\mathrm{r}} 1375.05\right.$ + 36.03): C, 42.56; H, 3.43; N, 7.94, S 13.63. Found: C, 42.53; H, 3.10; N, 7.95, S 13.77. FT-IR $\left(\mathrm{KBr}, \mathrm{cm}^{-1}\right)$ : $v(\mathrm{C}=\mathrm{N}) 1610(\mathrm{w}, \mathrm{br}) .{ }^{1} \mathrm{H}$ NMR $\left(400 \mathrm{MHz}, \mathrm{DMSO}-d_{6}\right)$ : $\delta 2.63\left(\mathrm{~s}, 6 \mathrm{H}, \mathrm{CH}_{3}\right), 5.32\left(\mathrm{~s}, 4 \mathrm{H}, \mathrm{H}^{8}\right), 7.02\left(\mathrm{~s}, 1 \mathrm{H}, \mathrm{H}^{11}\right)$, $7.12-7.20\left(\mathrm{~m}, 6 \mathrm{H}, \mathrm{H}^{5,6,9}\right), 7.29(\mathrm{t}, J=8.0 \mathrm{~Hz}, 1 \mathrm{H}$, $\left.\mathrm{H}^{10}\right), 7.38\left(\mathrm{~d}, J=8.0 \mathrm{~Hz}, 2 \mathrm{H}, \mathrm{H}^{7}\right), 7.58(\mathrm{~d}, J=4.0 \mathrm{~Hz}$, $\left.2 \mathrm{H}, \mathrm{H}^{4}\right)$. Crystals suitable for X-ray diffraction were obtained from $\mathrm{CH}_{2} \mathrm{Cl}_{2}: \mathrm{CH}_{3} \mathrm{OH}$ mixture.

\section{$2.3 X$-ray crystallography}

Intensity data of suitably sized crystal of $\mathbf{1}$ was collected on an Oxford Xcalibur S diffractometer (4-circle $\kappa$ goniometer, Sapphire-3 CCD detector, $\omega$ scans, graphite monochromator, and a single wavelength enhanced $\mathrm{X}$ ray source with $\mathrm{MoK} \alpha$ radiation). ${ }^{16 \mathrm{a}}$ Pre-experiment, data collection, data reduction, and absorption correction were performed with the CrysAlisPro software suite. ${ }^{16 \mathrm{~b}}$ Intensity data of suitably sized crystal of $\mathbf{3}$ was collected on a Bruker AXS SMART-APEX diffractometer with a CCD area detector and graphite monochromator. The frames were collected by $\omega, \phi$ and $2 \theta$ rotation at 10 s per frame with SMART. ${ }^{16 c}$ The measured intensities were reduced to $F^{2}$ and corrected for absorption with SADABS. ${ }^{16 \mathrm{~d}}$ The structures were solved by direct methods using SIR 92 which revealed the atomic positions, and refined using the SHELX-97 program package and SHELXL97 (within the WinGX program package). ${ }^{16 \mathrm{e}-16 \mathrm{~g}}$ Non-hydrogen atoms were refined anisotropically. $\mathrm{C}-\mathrm{H}$ hydrogen atoms were placed in geometrically calculated positions by using a riding model. Table S1 for crystallographic data of $\mathbf{1}$ and $\mathbf{3}$ can be found in Supplementary Information

\section{Results and Discussion}

\subsection{Characterization of $\mathbf{1 - 3}$}

Metallacycles $\mathbf{1}-\mathbf{3}$ were synthesized by self-assembly of benzimidazolyl derived ditopic ligands, $\mathrm{L}^{1}-\mathrm{L}^{3}$, with $\operatorname{AgOS}(\mathrm{O})_{2} \mathrm{CF}_{3}$ in $1: 1 \mathrm{CH}_{2} \mathrm{Cl}_{2}: \mathrm{CH}_{3} \mathrm{OH}$ in 93,70 and $83 \%$ yields, respectively (scheme 1 ). The complexes are air and moisture stable solids and soluble in common organic solvents. The FT-IR spectra of $\mathbf{1}-\mathbf{3}$ in $\mathrm{KBr}$ showed a band for $v_{\mathrm{C}=\mathrm{N}}$ at 1565,1562 and $1610 \mathrm{~cm}^{-1}$. These bands are shifted to lower frequencies compared 


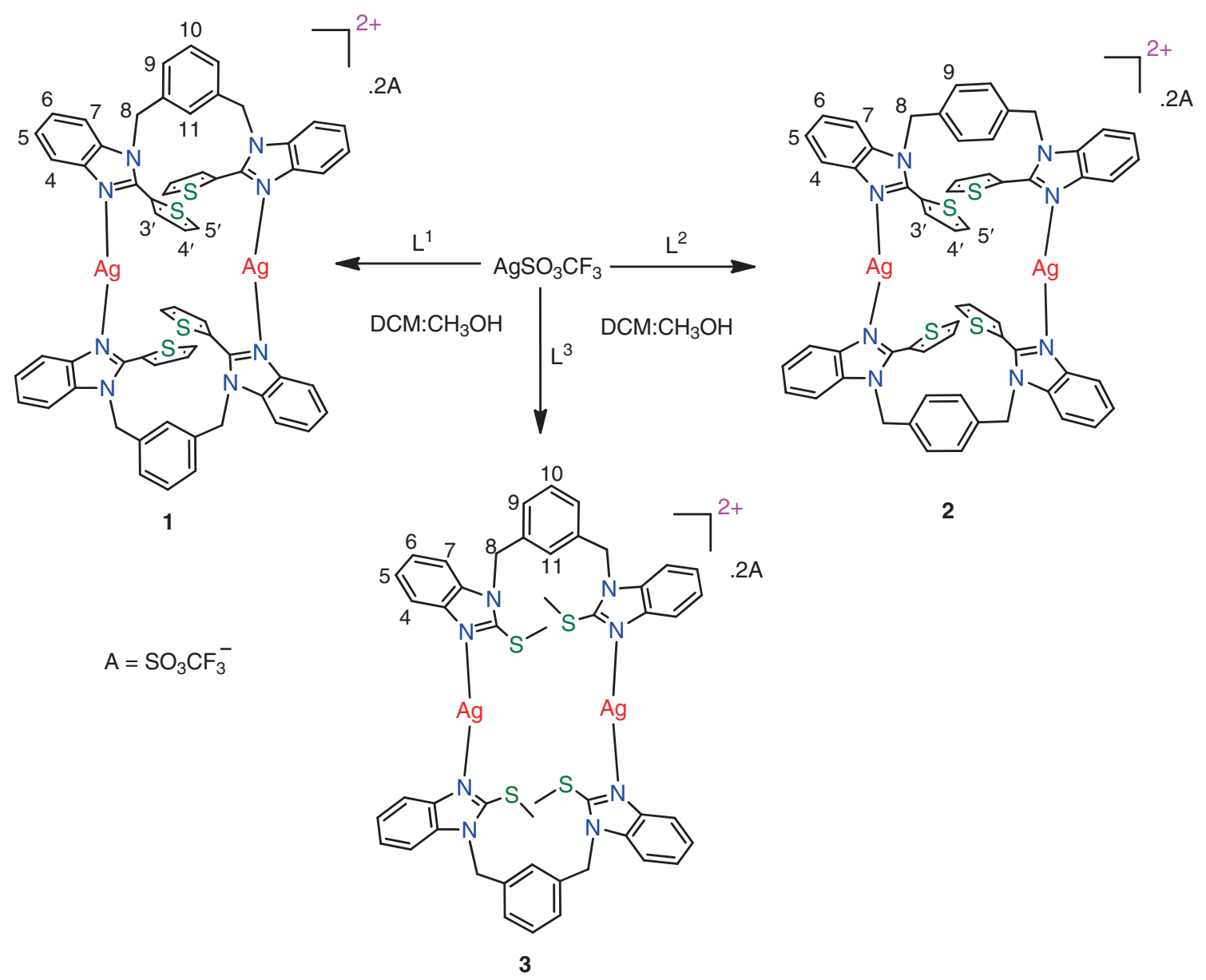

Scheme 1. Synthesis of metallacycles 1-3.

to those for the free ligands which reflect the weakening of $\mathrm{C}=\mathrm{N}$ bond due to bonding with silver ion.

The ${ }^{1} \mathrm{H}$ NMR spectra of $\mathbf{1 - 3}$ were recorded in $d_{6^{-}}$ $\mathrm{DMSO}$ at room temperature (figures S1-S8). The correlations between the peaks in ${ }^{1} \mathrm{H}$ NMR spectra of 1-3 were made with the help of ${ }^{1} \mathrm{H}-{ }^{1} \mathrm{H}$ COSY NMR spectra. The spectra of the complexes display one set of signals, suggesting the existence of a single species in solution. Another option is that the presence of conformers that undergo a rapid equilibrium in solution on the NMR time scale. The ${ }^{1} \mathrm{H}-\mathrm{NMR}$ spectrum of powder of $\mathbf{1}$ is similar to that of the crystals of $\mathbf{1}$. In the ${ }^{1} \mathrm{H}$ NMR spectrum of $\mathbf{1}$, protons $\mathrm{H}^{4}$ and $\mathrm{H}^{9}$ show slight downfield shift whereas the signals for other protons remain almost unchanged as compared to the free ligand (figure S1). The downfield shift is indicative of the coordination with the metal ion. In addition, remarkable upfield shift is observed for $\mathrm{H}^{11}$ by 1.99 ppm in comparison to the free ligand, which is probably due to the ring current effect from the nearby benzimidazolyl units. In the solid-state structure of $\mathbf{1}$, the conformation of $\mathrm{L}^{1}$ allows the positioning of $\mathrm{H}^{11}$ proton between the two face-to-face arranged benzimidazolyl rings (figure S4). This further supports the stability of the metallacyclic framework of $\mathbf{1}$ in solution. A similar observation was made for 3 where the signal for $\mathrm{H}^{11}$ proton was shifted upfield by comparatively a lesser value $(0.09 \mathrm{ppm})$, presumably due to the less aromatic clouds around the proton (figure S3). Similar effects have previously been observed for few silver metallacycles. ${ }^{8 \mathrm{a}}$ The $\mathrm{H}^{11}$ chemical resonance merged with $\mathrm{H}^{5,6,9}$ protons chemical resonances in the powder sample of $\mathbf{3}$. This may be due to the possibility of presence of various conformers due to rotation of the free functional units in the powder sample. The ${ }^{1} \mathrm{H}$ NMR spectrum of metallacycle $\mathbf{2}$ was largely similar to that of the free $\mathrm{L}^{2}$ (figure S2). The composition of the complexes was further supported by ESI-MS data (figures S8-S15). The molecular ion peaks for metallacycles $\mathbf{2}$ and $\mathbf{3}$ were observed at $\mathrm{m} / \mathrm{z}=$ 1369.0192 and 1225.0182, respectively, which confirm the formation of monocationic metallocyclic species $\left[\mathrm{Ag}(\mathrm{L})_{2}\left(\mathrm{OS}(\mathrm{O})_{2} \mathrm{CF}_{3}\right)\right]^{+}$(figures $\mathrm{S} 10$ and $\mathrm{S} 13$ ). The base 
peaks in the ESI-MS spectra of metallacycles 1, 2 and 3 can be seen at $m / z=1113.1631,1113.1635$ and 969.1624 respectively (figures S8, S11, S14). These can be assigned to another monocationic $\left[\mathrm{Ag}(\mathrm{L})_{2}\right]^{+}$species in solution. The identification of such a sub-unit in the MS spectra of all the three metallacycles leads to a generalization that monocationic species might be the key intermediate, that upon subsequent reaction with another silver ion, results in the final metallacycle. ${ }^{8 \mathrm{c}}$ Moreover, the dicationic metallocyclic species $\left[\mathrm{Ag}_{2} \mathrm{~L}_{2}\right]^{2+}$ was also identified in the ESI-MS spectra of all the three metallacycles (figures S9, S12, S15).

\subsection{X-Ray Diffraction Studies}

Single crystal X-ray diffraction studies of $\mathbf{1}$ and $\mathbf{3}$ revealed binuclear dicationic metallacyclic $\left[\mathrm{Ag}_{2} \mathrm{~L}_{2}\right]^{2+}$ motif and two triflate anions per formula unit (figure 2). Two ligands, act as molecular clip, coordinated with two silver ions using benzimidazolyl nitrogen atom (figure 2). The ligands take anticonformation in both the complexes in such a way that both thiophenyl/thiomethyl units in each ligand motif point in opposite directions. The two thiophenyl rings are non-coplanar with the benzimidazolyl plane (dihedral angle $=45^{\circ}$ and $71^{\circ}$ ) in 1 (figure 3). The $\mathrm{Ag}-\mathrm{N}$ bond lengths are comparable in

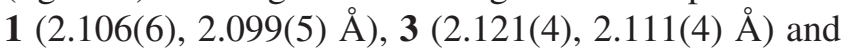
known Ag-imidazolyl/Ag-benzimidazolyl-based metallacycles $\left(\left[\mathrm{Ag}_{2} \mathrm{~L}_{2}\right]^{2+}(2.076-2.131 \AA)\right.$, where $\mathrm{L}=$ ditopic clip ligand). ${ }^{7,8}$ Slightly bent geometry is observed around the metal center $\left(\mathrm{N}(1)-\mathrm{Ag}-\mathrm{N}(4)=168^{\circ}\right.$ in $\mathbf{1}$ and $174.1^{\circ}$ in $\left.\mathbf{3}\right)$. The higher deviation from linearity for the $\mathrm{N}(1)-\mathrm{Ag}-\mathrm{N}(4)$ angle in $\mathbf{1}$ as compared to that in 3 is reflected in $\mathrm{Ag} \cdots \mathrm{Ag}$ distance (4.850 $\AA$ in 1 and $6.216 \AA$ in 3). The overall size of metallacyclic framework of $\mathbf{3}$ including van der Waals radii is $18.02 \AA$ (length) $\times 6.49 \AA$ (width). The observed differences related to the metallacyclic core in $\mathbf{1}$ and $\mathbf{3}$ can be attributed to the inward orientation of one of the two $\mathrm{S}-\mathrm{Me}$ groups on the ligand towards the metallacyclic core in 3.

Both the metallacycles display a variety of noncovalent interactions. In the crystal lattice of $\mathbf{1}$, the cationic metallacycle and triflate anion are connected through moderate to strong $\mathrm{C}-\mathrm{H} \cdots \mathrm{O}$ contacts $(2.59$ $2.62 \AA$ Á) and moderate $\mathrm{C}-\mathrm{H} \cdot \mathrm{F}$. F interactions (2.64 ̊̊). Further, metallacyclic units are connected with each other through moderate $\mathrm{C}-\mathrm{H} \cdots \pi$ interactions (2.89 ̊⿱) (figure 4). These interactions result in the formation of sheets which stack one over another resulting in a three-dimensional framework.

Metallacycle 3 displays similar type of non-covalent interactions. Molecules of $\mathbf{3}$ form a linear array through weak $\mathrm{C}-\mathrm{H} \cdots \pi$ interactions $(2.85$ Á). The triflate ions inter-connect the individual metallacyclic arrays to form a 3D-network through moderate to strong $\mathrm{C}-\mathrm{H} \cdots \mathrm{O}(2.29-2.70$ Á) interactions where one of the oxygens undergo a trifurcated H-bonding interaction with three hydrogen atoms simultaneously (figure 5).
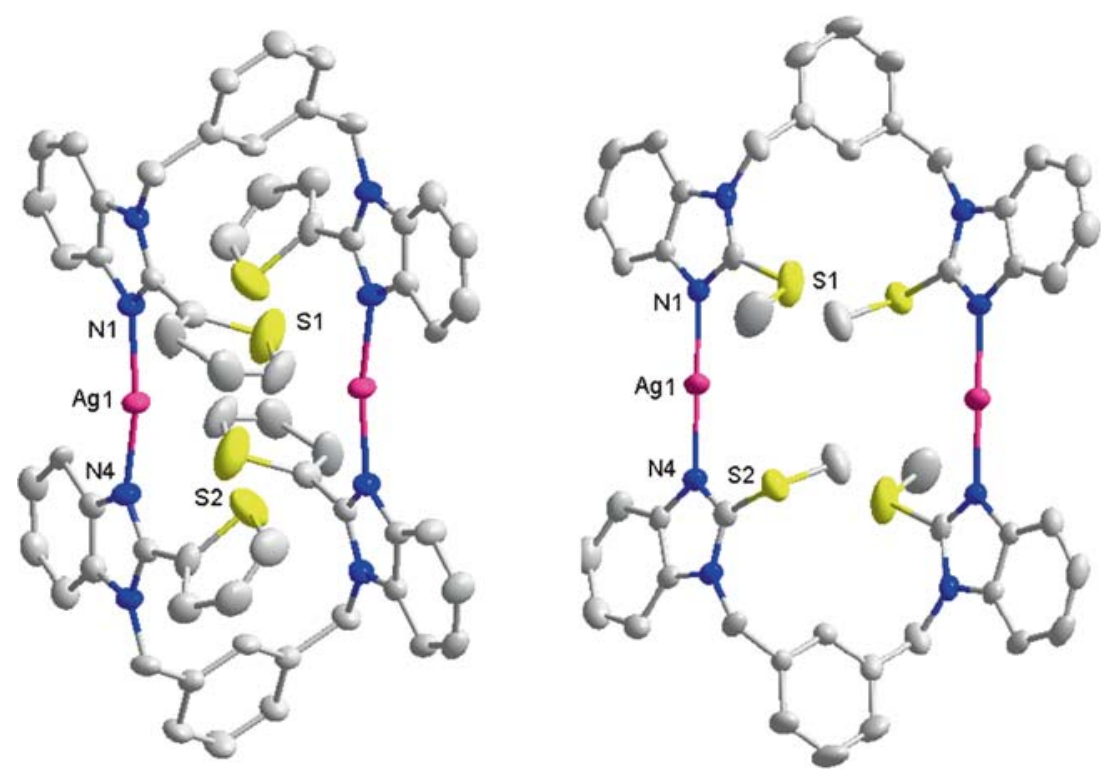

Figure 2. The ORTEP representations of $\mathbf{1}$ (left) and $\mathbf{3}$ (right) at $30 \%$ probability level. Hydrogen atoms and triflate ions have been removed for clarity. Selected bond distances $(\AA)$ and angles (degree) 1/3: Ag1-N1 2.106(6)/ 2.121(4), Ag1-N4 2.099(5)/2.111(4), N1-Ag1-N4 168.1(2)/174.1(2). 

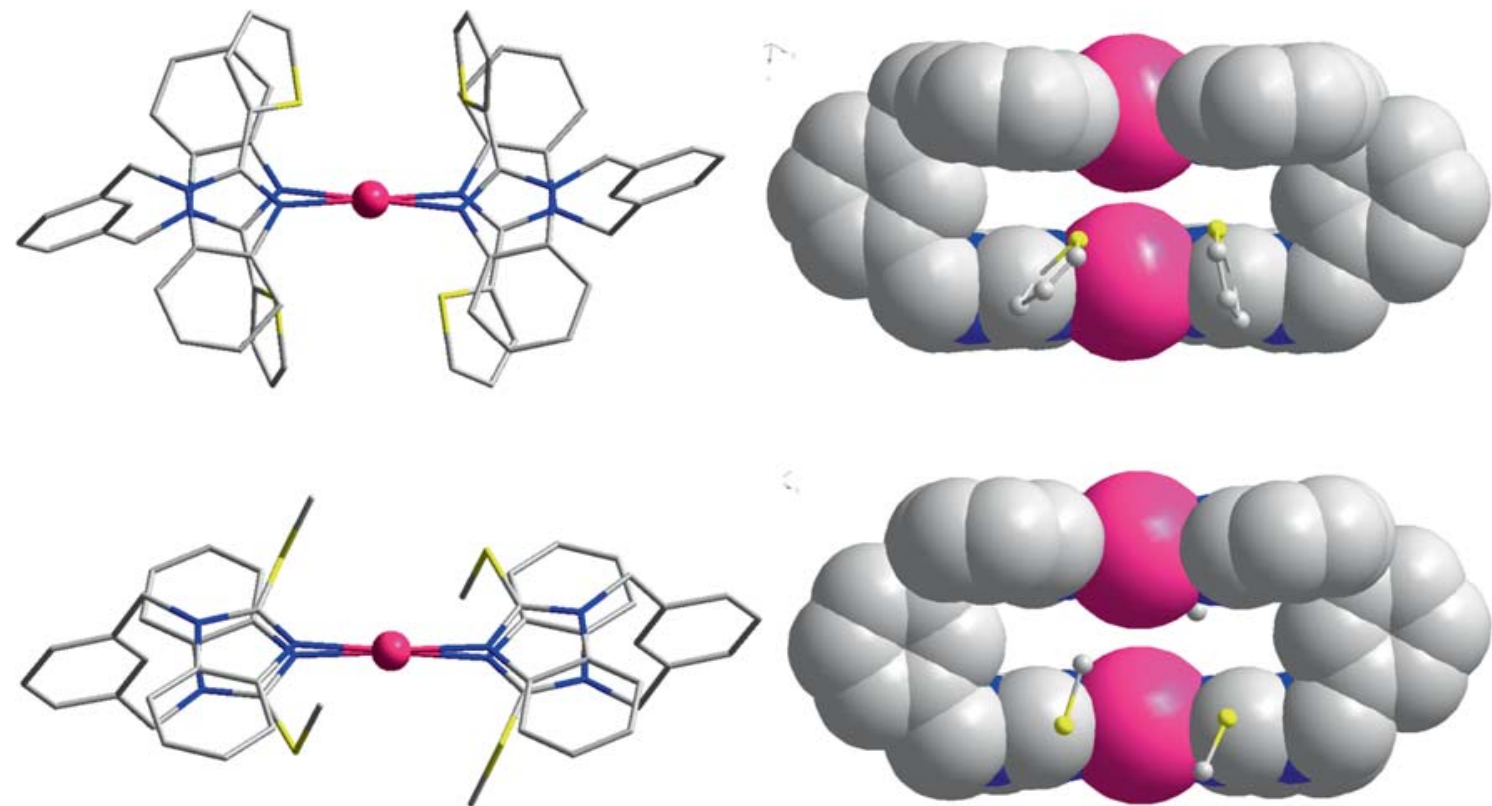

Figure 3. Two different views of molecular structures of $\mathbf{1}$ (top) and $\mathbf{3}$ (bottom). Hydrogen atoms and triflate ions have been removed for clarity. $\mathrm{C}$ - gray, $\mathrm{N}$ - blue, $\mathrm{S}$ - yellow, $\mathrm{Ag}$ - pink.
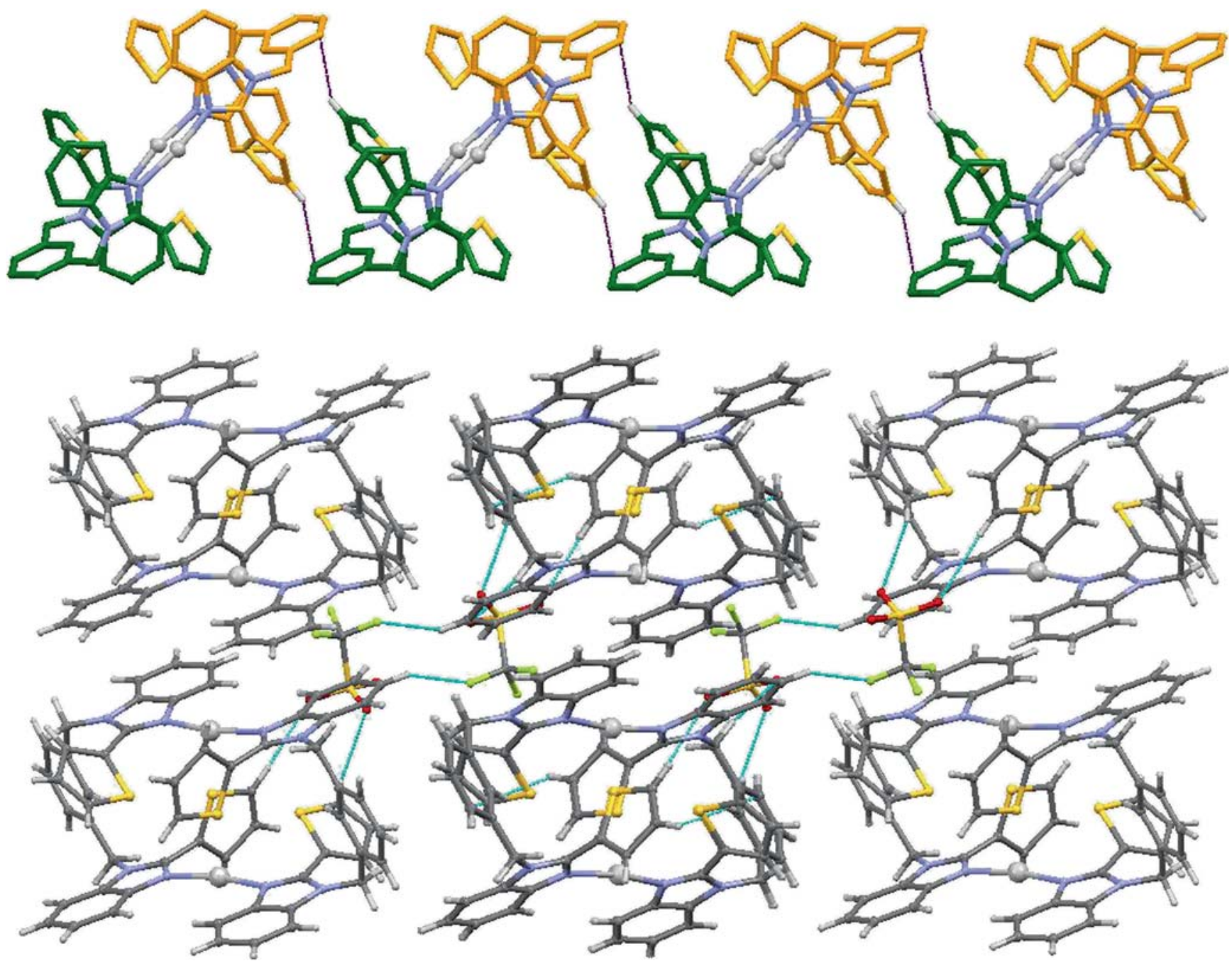

Figure 4. The $\mathrm{C}-\mathrm{H} \cdots \pi$ (top) interactions in crystal structure of metallacycle 1. $\mathrm{C}-\mathrm{H} \cdots \mathrm{O}, \mathrm{C}-\mathrm{H} \cdots \pi$ and $\mathrm{C}-\mathrm{H} \cdots \mathrm{F}$ interactions present in the crystal lattice of $\mathbf{1}$ leading to the formation of sheets in the $b c$-plane. 

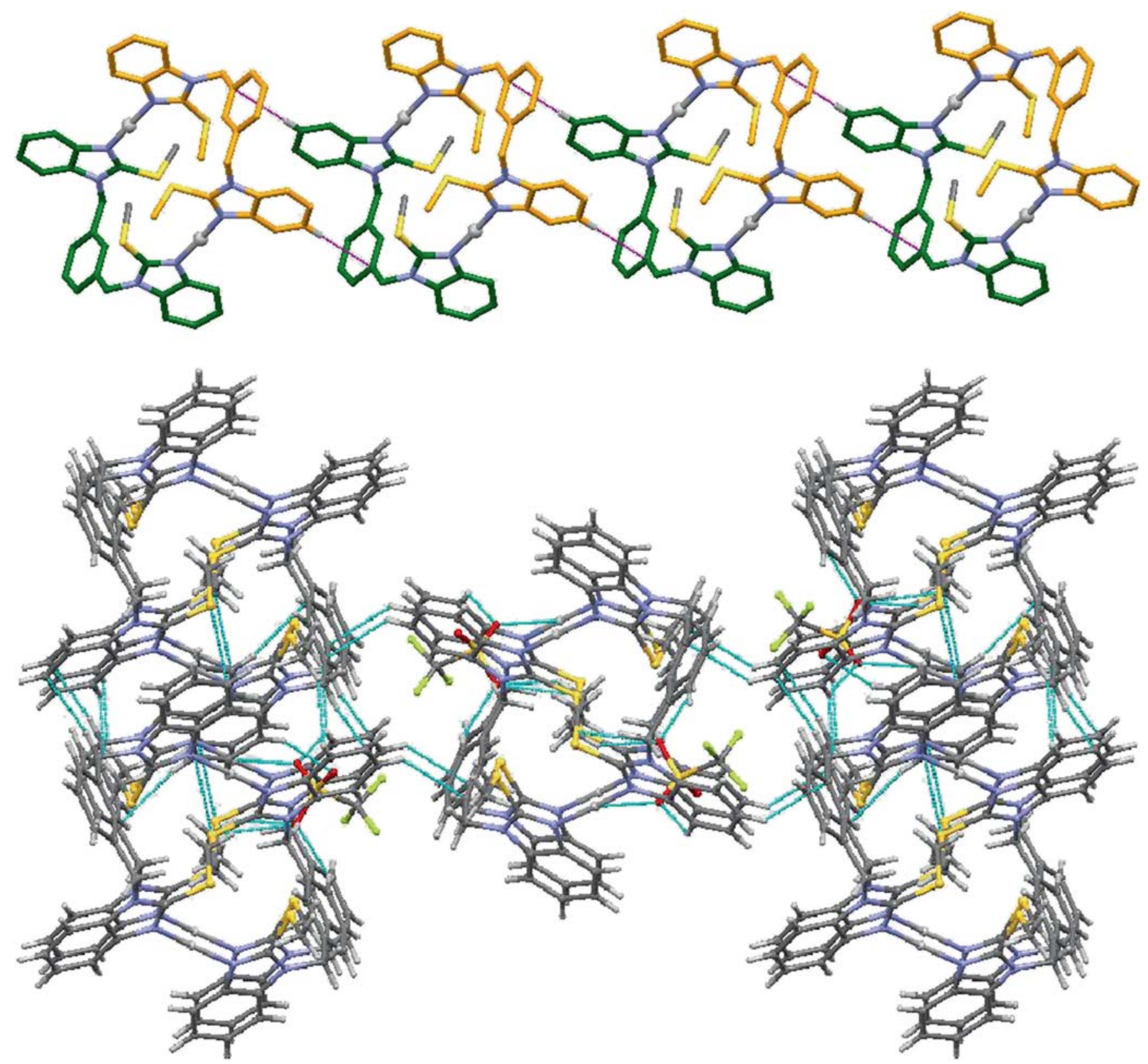

Figure 5. The $\mathrm{C}-\mathrm{H} \cdots \pi$ interactions (top) in crystal structure of metallacycle 3 . The $\mathrm{C}-\mathrm{H} \cdots \mathrm{O}$ and $\mathrm{C}-\mathrm{H} \cdots \pi$ interactions present in the crystal lattice of $\mathbf{3}$ leading to the formation of sheets in the $a b$-plane.

\section{Conclusions}

A new family of metallacycles with covalently attached free thiophenyl/thiomethyl units was synthesized using $\operatorname{AgOS}(\mathrm{O})_{2} \mathrm{CF}_{3}$ and ditopic ligands and characterized by using crystallographic and spectroscopic techniques. Influence of substituents on the metallacyclic core upon the size of the metallacyclic framwork is observed which can be helpful in designing the metallacycles with desired cavity size for host-guest activity for practical utilities. Moreover, the uncoordinated free thiophenyl/thiomethyl units on the metallacyclic framework will be utilized for further coordination. We plan to explore this aspect in our future work.

\section{Supplementary Information}

Copies of NMR, mass spectra and crystallographic data table are available at www.ias.ac.in/chemsci. CCDC 1400518 and 1400519 , contain the supplementary crystallographic data for $\mathbf{1}$ and $\mathbf{3}$. These data can be obtained free of charge via http://www.ccdc.cam.ac. uk/conts/retrieving.html, or from the Cambridge Crystallographic Data Centre, 12 Union Road, Cambridge 
CB2 1EZ, UK; fax: (+44) 1223-336 033; or e-mail: deposit@ccdc.cam.ac.uk.

\section{Acknowledgements}

We thank USIC \& Department of Chemistry, University of Delhi, and School of Chemistry, University of Hyderabad for financial support and instrumentation facilities. SY thanks UGC for Junior Research fellowship.

\section{References}

1. (a) Khlobystov A N, Blake A J, Champness N R, Lemenovskii D A, Majouga A G, Zyk N V and Schröder M 2001 Coord. Chem. Rev. 222 155; (b) Steel P J and Fitchett C M 2008 Coord. Chem. Rev. 252 990; (c) Young A G and Hanton L R 2008 Coord. Chem. Rev. 252 1346; (d) Slenters T V, Sagué J L, Brunetto P S, Zuber S, Fleury A, Mirolo L, Robin A Y, Meuwly M, Gordon O, Landmann R, Daniels A U and Fromm K M 2010 Materials 3 3407; (e) Burgess J and Steel P J 2011 Coord. Chem. Rev. 255 2094; (f) Fromm K M 2013 Appl. Organomet. Chem. 27683

2. (a) Grapperhaus C A, Li M and Mashuta M S 2002 Chem. Commun. 1792; (b) Hannon M J, Painting C L, Plummer E A, Childs L J and Alcock N W 2002 Chem. Eur. J. 8 2225; (c) Steel P J and Sumby C J 2002 Chem. Commun. 322; (d) Bu X-H, Xie Y-B, Li J-R and Zhang R-H 2003 Inorg. Chem. 42 7422; (e) Dong Y-B, Zhang H-Q, Ma J-P, Huang R-Q and Su C-Y 2005 Cryst. Growth Des. 5 1857; (f) Li X-P, Zhang J-Y, Pan M, Zheng S-R, Liu Y and Su C-Y 2007 Inorg. Chem. 46 4617

3. (a) Caradoc-Davies P L and Hanton L R 2003 Dalton Trans. 1754; (b) Sague J L, Meuwly M and Fromm K M 2008 Cryst. Eng. Commun. 10 1542; (c) Deng Z-P, Zhu L-N, Gao S, Huo L-H and Ng S W 2008 Cryst. Growth Des. 8 3277; (d) Wei W, Wu M, Huang Y, Gao Q, Zhang Q, Jiang F and Hong M 2009 Cryst. Eng. Commun. 11 576; (e) Kilpin K J, Gower M L, Telfer S G, Jameson G B and Crowley J D 2011 Inorg. Chem. 50 1123; (f) Kim C W, Noh T H and Jung O-S 2011 Inorg. Chim. Acta 365 496; (g) Lee H, Kim E J, Ahn J, Noh T H and Jung OS 2012 J. Mol. Struc. 1010 111; (h) Wei W, Yu H, Jiang F, Liu B, Ma J and Hong M 2012 Cryst. Eng. Commun. 14 1693; (i) Wan C-Q, Al-Thabaiti S A, Chen X-D and Mak T C W 2013 Eur. J. Inorg. Chem. 5265; (j) Joardar S, Roy, Samanta S and Dutta A M 2015 J. Chem. Sci. 127 1819; (k) Li Y, Zhang W L, Du H J, Wang C H, Lu Y B and Niu Y Y 2015 J. Chem. Sci. 127 1513; (1) Gupta A, Srivastava A K and Boomishankar R 2015 J. Chem. Sci. 127619

4. (a) Dias H V R, Diyabalanage H V K and Gamage C S P 2005 Chem. Commun. 1619; (b) Hettiarachchi C V, Rawashdeh-Omary M A, Korir D, Kohistani J, Yousufuddin M and Dias H V R 2013 Inorg. Chem. 52 13576

5. (a) Reger D L, Foley E A and Smith M D 2010 Inorg. Chem. 49 234; (b) Gardinier J R, Tatlock H M, Hewage J S and Lindeman S V 2013 Cryst. Growth Des. 133864
6. (a) Song R-F, Xie Y-B and Bu X-H 2003 J. Mol. Struct. 657 311; (b) Wu C-J, Lin C-Y, Cheng P-C, Yeh C-W, Chen J-D and Wang J-C 2011 Polyhedron 302260

7. du Plessis M, Smith V J and Barbour L J 2014 Cryst. Eng. Commun. 164126

8. (a) Su C-Y, Cai Y-P, Chen C-L, Smith M D, Kaim W and zur Loye H-C 2003 J. Am. Chem. Soc. 125 8595; (b) Chen C-L, Tan H-Y, Yao J-H, Wan Y-Q and Su C-Y 2005 Inorg. Chem. 44 8510; (c) Raehm L, Mimassi L, Guyard-Duhayon C, Amouri H and Rager M N 2003 Inorg. Chem. 425654

9. (a) Maekawa M, Kitagawa S, Kuroda-Sowa $\mathrm{T}$ and Munakata M 2006 Chem. Commun. 2161; (b) Dash C, Mobin S M and Ghosh P 2011 J. Chem. Sci. 12397

10. Zhou J, Liu X, Zhang Y, Li B and Zhang Y 2006 Inorg. Chem. Commun. 9216

11. Laye R H 2007 Inorg. Chim. Acta 360439

12. (a) Chen C-L, Yu Z-Q, Zhang Q, Pan M, Zhang J-Y, Zhao C-Y and Su C-Y 2008 Cryst. Growth Des. 8 897; (b) Mudsainiyan R, Jassal A K, Arora M and Chawla S K 2015 J. Chem. Sci. 127 849; (c) Murugavel R, Anantharaman G, Krishnamurthy D, Sathiyendiran M and Walawalkar M G 2000 Proc. Indian Acad. Sci. (J. Chem. Sci.) 112273

13. Purohit C S and Verma S 2007 J. Am. Chem. Soc. 129 3488

14. Pogozhev D, Baudron S A and Hosseini M W 2011 Dalton Trans. 40437

15. (a) Shankar B, Rajakannu P, Kumar S, Gupta D, Kannan T and Sathiyendiran M 2011 Inorg. Chem. Commun. 14 374; (b) Gupta D, Rajakannu P, Shankar B, Shanmugam R, Hussain F, Sarkar B and Sathiyendiran M 2011 Dalton Trans. 40 5433; (c) Shankar B, Hussain F and Sathiyendiran M 2012 J. Organomet. Chem. 719 26; (d) Rajakannu P, Hussain F, Shankar B and Sathiyendiran M 2012 Inorg. Chem. Commun. 26 46; (e) Shankar B, Elumalai P, Jackmil P J, Kumar P, Singh S and Sathiyendiran M 2013 J. Organomet. Chem. 743 109; (f) Shankar B, Elumalai P, Hussain F and Sathiyendiran M 2013 J. Organomet. Chem. 732 130; (g) Rajakannu P, Elumalai P, Mobin S M, Lu K-L and Sathiyendiran M 2013 J. Organomet. Chem. 743 17; (h) Shankar B, Sahu S, Deibel, N, Schweinfurth D, Sarkar B, Elumalai P, Gupta D, Hussain F, Krishnamoorthy G and Sathiyendiran M 2014 Inorg. Chem. 53 922; (i) Gupta D, Rajakannu P, Shankar B, Hussain F and Sathiyendiran M 2014 J. Chem. Sci. 126 1501; (j) Rajakannu P, Mobin S M and Sathiyendiran M 2014 J. Organomet. Chem. 771 68; (k) Shankar B, Elumalai P, Sathiyashivan D and Sathiyendiran M 2014 Inorg. Chem. 53 10018; (1) Shankar B, Elumalai P, Shanmugam R, Singh V, Masram D T and Sathiyendiran M 2013 Inorg. Chem. 52 10217; (m) Elumali P, Kanagaraj R, Marimuthu R, Shankar B, Kalita A C and Sathiyendiran M 2015 Dalton Trans. 4411274

16. (a) ENHANCE, Oxford Xcalibur Single Crystal Diffractometer, version 1.171.34.40, Oxford Diffraction Ltd, Oxford, U.K., 2006; (b) CrysAlisPro, version 1.171.34.40, Oxford Diffraction Ltd, Oxford, U.K., 2006; (c) SMART, Bruker Molecular Analysis Research Tool, version 5.0, Bruker Analytical X-ray Systems, 
Madison, WI 2000; (d) SAINT-NT, version 6.04, Bruker Analytical X-ray Systems, Madison, WI 2001; (e) Altomare A, Cascarano G, Giacovazzo C, Guagliardi A, Burla M C, Polidori G and Camalli M 1994 J. Appl.
Crystallogr. 27 435; (f) Sheldrick G M SHELXL-97, Program for crystal structure refinement, University of Gottingen, Gottingen, Germany 1997; (g) Farrugia L J 1999 J. Appl. Crystallogr. 32837 